\title{
Level of Female Literacy and Its Differentials in Haryana: A Lowest Sex Ratio State of India
}

\author{
Ravinder Jangra ${ }^{1}$, S. P. Kaushik ${ }^{2}$ \\ ${ }^{1}$ Research Scholar, Department of Geography, Kurukshetra University, Kurukshetra (Haryana), India \\ ${ }^{2}$ Professor, Department of Geography, Kurukshetra University, Kurukshetra (Haryana), India
}

\begin{abstract}
The study reveals the tehsil-wise trend of female literacy rate in Haryana because it is presumed that the female literates can easily understand the consequences of descending sex ratio. So, the purpose of the paper is to describe and interpret the regional aspects of the urban-rural differentials in female literacy during 1991, 2001 and 2011. It is primarily based on census data. Data is processed with simple statistical techniques such as percentage and multiple correlations. Attempt has been made to identify the correlates of female literacy in an agro-based economy. It is noted that the total female literacy rate has increased significantly during the study period. However, there are wide gaps in urban-rural female literacy. Comparatively, the increase is more remarkable in rural areas and gap is narrowing down.
\end{abstract}

Keywords: Level of Female Literacy, Urban-Rural Literacy and Differential Index, Correlation Matrix

\section{Introduction}

Literacy is a human right, a tool of personal empowerment and a means for social and human development (Shakir, 2012), main components of Human Development Index (Khan, 2004; Jhariya, 2014) and one of the important indicators of the socio-economic and culture development (Azim, 2005), which is good measure of human process towards modernization (Sule \& Barakade, 2012). It is a basic parameter for analyzing the female progression (Ramotra, 2003) and literacy rate also indicates the women's status and autonomy in society (Frey \& Field, 2000; Magadi et al., 2007). The education of women is closely inter-related with their social position and advancement in education level improved their social status and corresponding change in its character. Therefore, it is the most significant instrument for improving women's status all over the world and changing women's subjugated position in society (Kamat, 1976). The education of women as a strategic investment in human resources, have a tremendous impact on their own development as well as their families and communities. According to the Census of India, person who can read and write with understanding in any language aged above six year considered as literate (Som \& Mishra, 2014). ESCAP, 2010 observed that the Asia-Pacific region has three-quarter illiterate population of the world and it is also the biggest and most difficult issues in developing countries (Shafiqullah, 2011) of which India is a part, second largest populated country are characterized by great disparity between urbanrural, male-female and young-aged (Krishan \& Shyam, 1978). India has effective literacy rate of 74.04 percent. It is to be noted that 82.14 percent male and 65.46 percent female are literate meaning thereby a large gender gap in literacy (Census of India, 2011). On the other hand, decline in sex ratio has become a serious problem in India and it is presumed that literates mainly females can easily understand the consequences of sinking sex ratio (Chaudhari \& Ahire, 2015). The study area Haryana has total literacy rate is 75.55 and 22th ranks in India. It has a wide gap between male and female literacy which accounts 84.06 and 65.94 respectively and also have females per thousand males in 2011 was 879 against nation average of 940 in 2011 which is also less than national average. So, keeping in view the above discussion the present study made an attempt to analyze the variations in the level of female literacy and its rural-urban differentials at tehsil level, Haryana.

\section{Objectives}

The analysis has been initiated to fulfill the following objectives:-

- To analyze the spatio-temporal pattern in the female literacy, Haryana for the year 1991, 2001 and 2011 and change during the study period.

- To examine the urban-rural literacy and its differentials in the study area.

\section{Study Area}

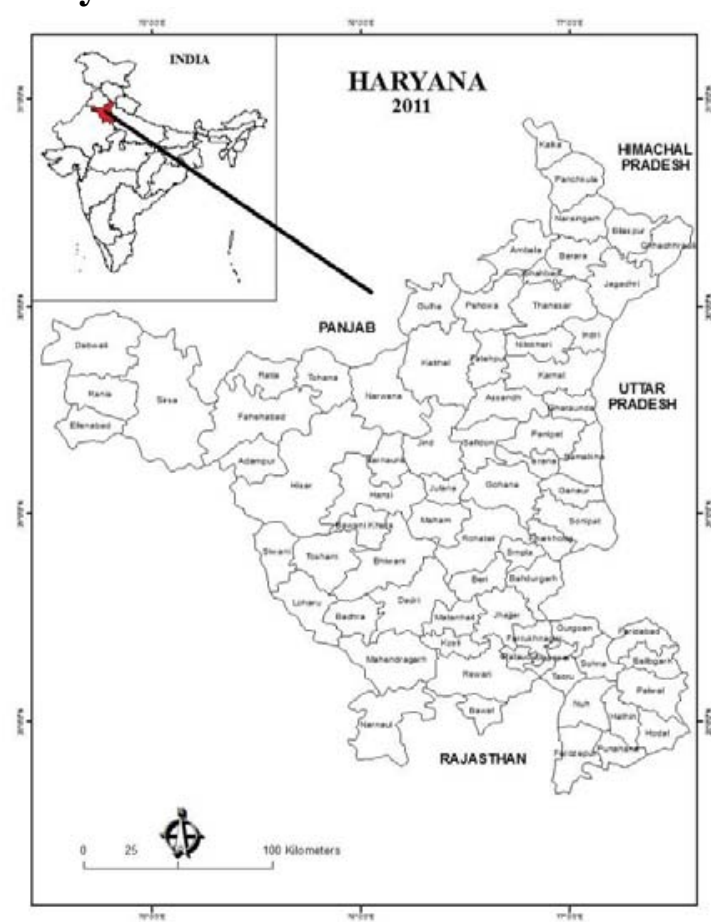

Figure 1: Location map 


\section{International Journal of Science and Research (IJSR) \\ ISSN (Online): 2319-7064 \\ Index Copernicus Value (2013): 6.14 | Impact Factor (2015): 6.391}

Present study pertain Haryana state which is located between $27^{\circ} 39^{\prime} \mathrm{N}$ to $30^{\circ} 55^{\prime} \mathrm{N}$ latitudes and $74^{\circ} 28^{\prime} \mathrm{E}$ to $77^{\circ} 36^{\prime} \mathrm{E}$ longitudes in the north-western part of India (Fig. 1). As per 2011 census, the total population of Haryana is 2.53 crore (1.35 crore males and 1.18 crore females) which accounts 2 percent of the total population of India. Haryana is the 16th largest state of India and is cover an area of 44,212 sq. km with a population density of 573 persons.

\section{Data Base and Methodology}

The study has been accomplished mainly through secondary data, collected from primary census abstract of Haryana published by census of India 2011. In 2011, there were 74 tehsils in the state while in 1991 these were only 53. For the sake of comparison, newly formed tehsils has been treated as a part of the past unit. So the 1991 administrative boundary are adopted to compare the relevant data and merge all tehsils boundaries according to the administrative boundary of 1991. Differential index of urban-rural literacy at tehsil level has been computed and displayed by bivariate method for the year 1991, 2001 and 2011.Thereafter, selected independent variables namely, pupil-teacher ratio (PTR), population (0-6 age group), school/100 $\mathrm{km}^{2}$., population/school, sex-ratio, percent of urban population, male literacy, BPL population ratio, rural literacy and urban literacy are co-related with dependent variable (female literacy rate) using Pearson co-efficient of correlation method by SPSS 16 with level of significance.

\subsection{Quantitative Analysis}

To calculate the level of literacy formula which is used by census of India in 1991 is adopted.

$$
\text { Literacy Rate }=\frac{\text { Literate Population }}{\text { Total Population-(0-6 Age group })} \times 100
$$

Urban-rural differential in literacy rate is calculated by using the following formula given by Krishna \& Shyam, 1978. Out of the 53 tehsils, 3 tehsils in 1991 and 2001 were entirely rural and to this reason the differential of these tehsils was not applicable. The differential can be absolute or relative.

$$
\mathrm{ID}=\frac{\mathrm{U}-\mathrm{R}}{\mathrm{T}}
$$

Where:

$$
\begin{aligned}
& \text { ID }=\text { index of urban-rural differential. } \\
& \mathrm{U}=\text { percentage of literates in urban population. } \\
& \mathrm{R}=\text { percentage of literates in rural population. } \\
& \mathrm{T}=\text { percentage of literates in total population. }
\end{aligned}
$$

For India, 2011 this index would be:- $\frac{84.11-67.77}{72.99}=0.22$

The discussion in the present paper is based on the indexes values obtained which were calculated in the same way for various tehsils of Haryana.

\section{Results and Discussion}

Female education is the main factor resulting in social change as well as changes in economic, political or legal structure which consequently affect the social situation of women, thinking and practice (Kamat, 1976). Thus, the present study focuses upon spatial pattern and urban-rural differential in female's literacy and tries to identify its correlates.

\subsection{Spatio-Temporal Analysis}

The female literacy rate was used as a proxy for women's status (McTavish, et al., 2010) and its spatio-temporal scenario is changing with the passage of time (Fig.2).

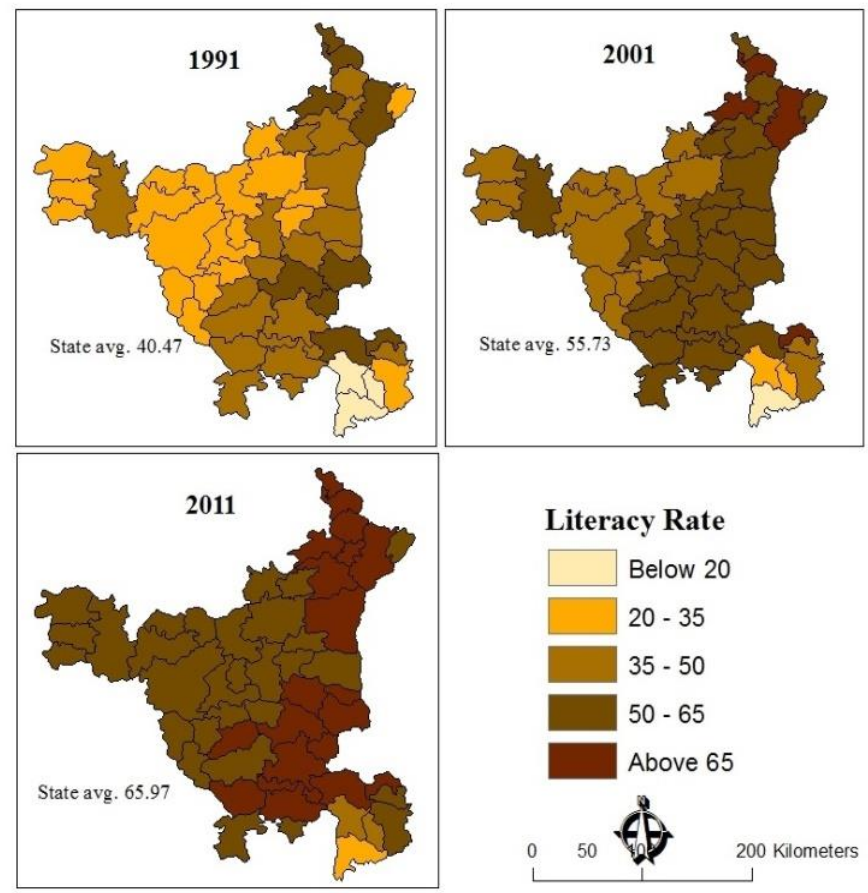

Figure 2: Female literacy rate in 1991, 2001 and 2011

It was only 40.47 percent in 1991 which increased to 65.97 percent in 2011. The lowest literacy rate has been recorded constantly in Nuh, Hathin, Punahana and Ferozapur-Jhirka tehsils (tehsils of Mewat district) in south Haryana. It is mainly occupied by Muslims and due to their traditional customs and backwardness they give less attention to female education. There has a large disparity between male and female literacy rates in backward communities (Ramotra, 2003). Consistently, level of female literacy is significantly high in eastern Haryana along national highway-1 which join state and national capitals. Therefore, adjoining areas of the capital cities such as Ambala, Panchkula, Kalka and Jagadhari tehsils in the north-east and NCR except Mewat in the south displays relatively higher level of female literacy. Secondly, level of urbanization and industrialization is high in this region which provides congenial environment for female literacy.

\subsection{Urban-Rural Differentials}

There is wide gap in female literacy between urban and rural areas. However, it is narrowing down with passage of time Tehsils are grouped into four categories on the basis of the urban-rural differential index to understand the spatial patterns in female literacy (Fig. 3). The differential index reflects a positive scenario in Haryana which shows a sharp decline from 0.78 in 1991 to 0.26 in 2011 . It clearly indicates that the person who lives in rural areas have become 


\section{International Journal of Science and Research (IJSR) \\ ISSN (Online): 2319-7064 \\ Index Copernicus Value (2013): 6.14 | Impact Factor (2015): 6.391}

conscious in the arena of females education but in the Muslim dominated Mewat district comprising the tehsils of Ferozepur-jhirka, Hathin and Nuh consistently depicts the high U-R differential. Apart from that largely agrarian tehsils of Dabwali and Fatehabad in the north-west region also show similartrends.

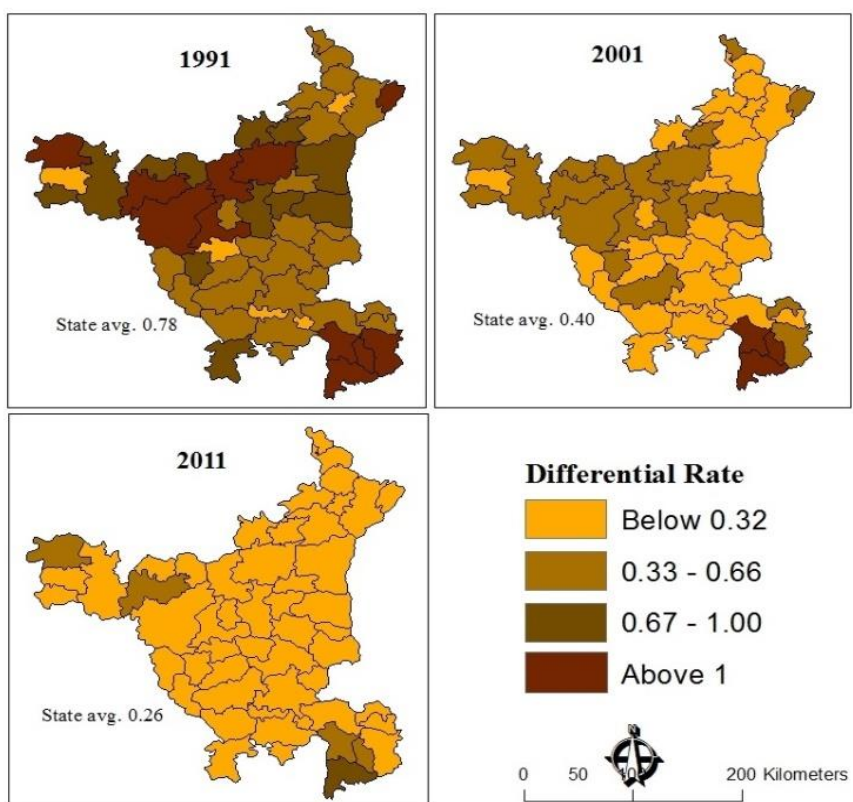

Figure 3: Urban-rural differential of female literacy in 1991, 2001 and 2011

The female literacy rate observed in urban areas is more than the state average while in the rural it is below that (Fig. 4).

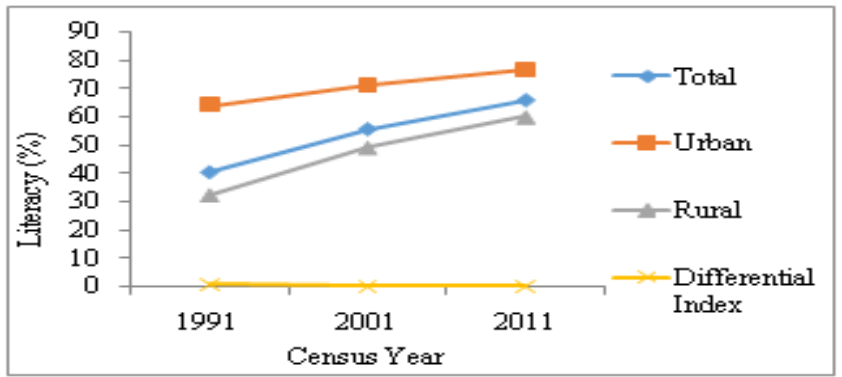

Figure 4: Growth and differential of female literacy in 1991, 2001 and 2011

\subsection{Pattern of Urban-Rural Literacy}

A statistical analysis of tehsils data revealed that the urban and rural literacy rates are marked by a positive correlation. Some deviations from this pattern may also be noted that Gulha, Rania, Ellenabad, Ferozepur-Jhirka, Siwani, Tosham and Loharu in the west region and Nuh and Palwal tehsils in the south have an incessantly low literacy rate in both urban as well as rural areas (Fig.5). Though, urban female literacy in western region is comparable to that of eastern but there is wide gap in rural areas whereas the eastern half of the state except Mewat district displays significant improvement in both rural as well as urban areas. Mewat has low literacy in both urban as well as rural areas consistently over a long period of time owing to social discrimination meted to females. The society is highly conservative and deny right to education to females. Female education is almost a taboo if the institution is not available in their village or at reasonable distance from their house due to which only a friction of them enrolled to the higher level. Even the male literacy is very low. The disparity between the urban and rural areas is a manifestation of the nature and quality of relationship between the two.
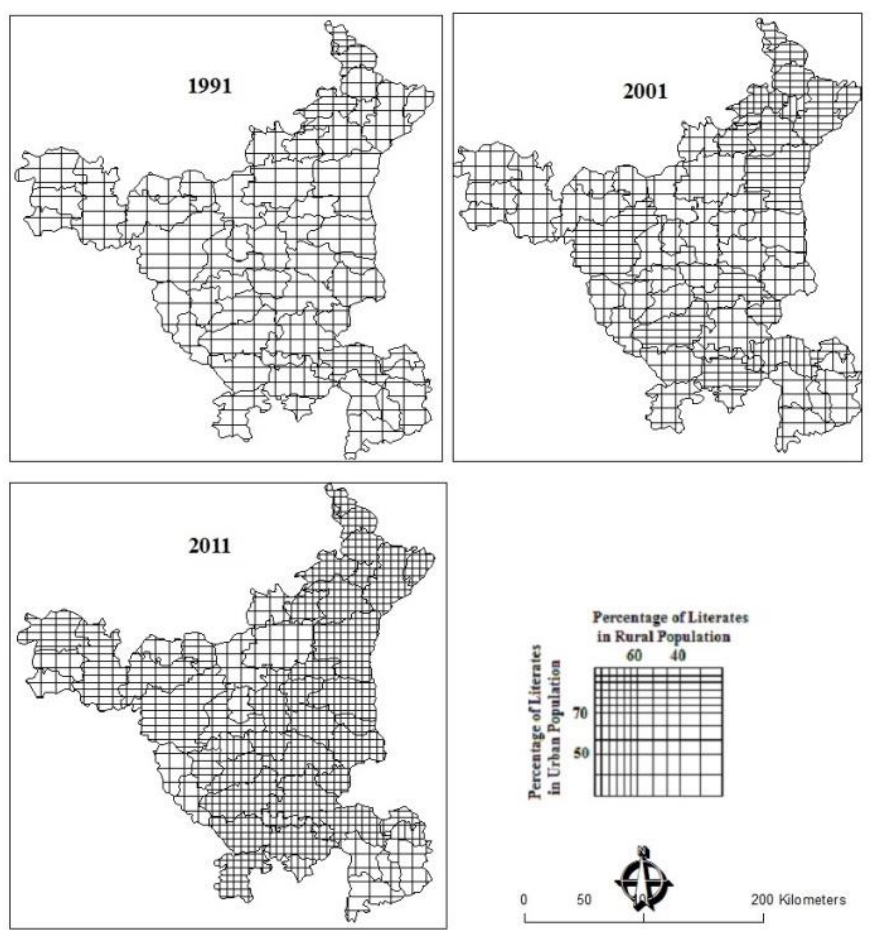
200 Klometers

Figure 5: Urban-rural female literacy rate in 1991, 2001 and 2011

\subsection{Changes in Female Literacy, 1991-2011}

Fig. 6 demonstrates the low change in female literacy in two decades during 1991 to 2011 in the tehsils which had high literacy rate earlier whereas traditionally low literacy areas of

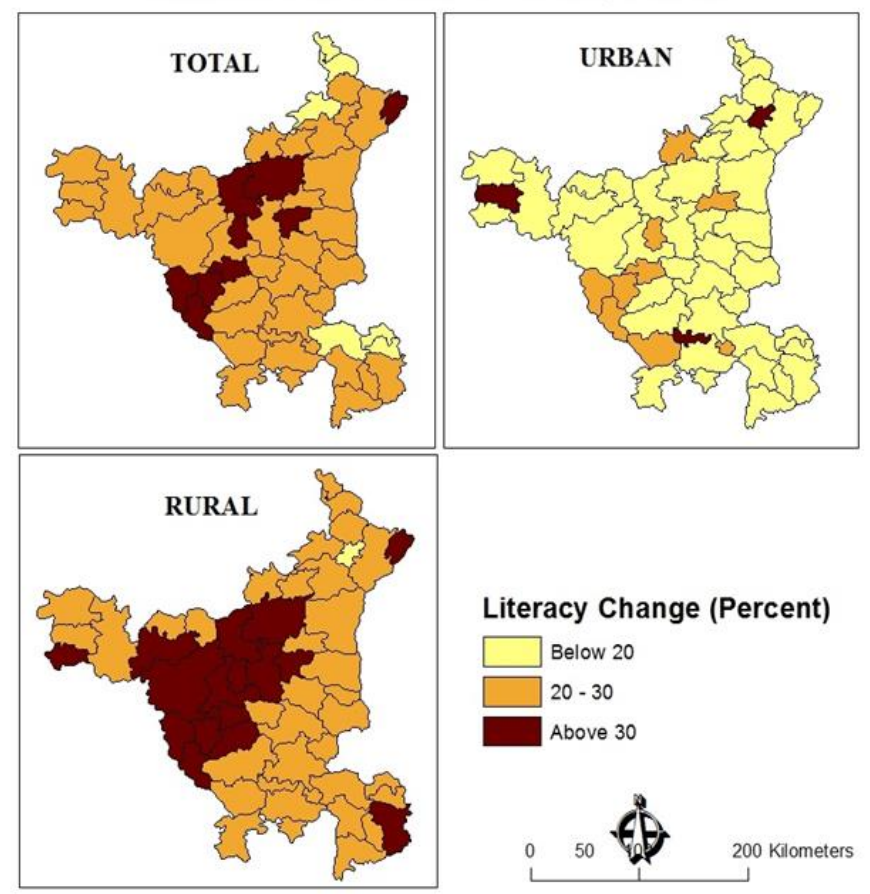

Figure 6: Change in female literacy rate, 1991-2011 


\section{International Journal of Science and Research (IJSR) \\ ISSN (Online): 2319-7064}

Index Copernicus Value (2013): 6.14 | Impact Factor (2015): 6.391

district Jind, Kaithal, Hisar, Fatehabad and Sirsa depicts greater change in both rural and urban areas. Moreover, this change is sharper in rural areas. There are three tehsils in urban female literacy (Rania, Kosli and Jagadari) which have experienced change of more than 30 percent. Tehsils which have more urban population (Kalka, Panchkula, Ambala, Gurgaon, Faridabad and Ballabgarh) in 1991 came under the category of low percent change due to previously high female literacy. Ironically, Mewat which is part of NCR and near to millennium city Gurgaon and industrial city Faridabad display low and moderate change in urban and rural areas respectively.

\subsection{Correlation Analysis}

Correlation matrix has been prepared to find out the relationship between different parameters and it is presented in table 4 where 11 criteria (female literacy rate, teacherpupil ratio, population (0-6), school/100sq $\mathrm{km}$., population/school, sex-ratio, urban population, male literacy, BPL ratio, rural literacy and urban literacy) are compared against each other (Table 3).

Table 3: Correlation with different variables

\begin{tabular}{|l|c|c|c|c|c|c|c|c|c|c|c|}
\hline & $\begin{array}{c}\text { Female } \\
\text { Literacy }\end{array}$ & $\begin{array}{c}\text { Pupil- } \\
\text { teacher } \\
\text { ratio }\end{array}$ & $\begin{array}{c}\text { Population } \\
(0-6)\end{array}$ & $\begin{array}{c}\text { School/ } \\
100 \mathrm{sq} . \mathrm{km}\end{array}$ & $\begin{array}{c}\text { Population/ } \\
\text { school }\end{array}$ & $\begin{array}{c}\text { Sex } \\
\text { ratio }\end{array}$ & Urbanization & $\begin{array}{c}\text { Male } \\
\text { literacy }\end{array}$ & $\begin{array}{c}\text { BPL } \\
\text { ratio }\end{array}$ & $\begin{array}{c}\text { Rural } \\
\text { literacy }\end{array}$ & $\begin{array}{c}\text { Urban } \\
\text { literacy }\end{array}$ \\
\hline Female Literacy & 1 & & & & & & & & & & \\
\hline Pupil- teacher ratio & .151 & 1 & & & & & & & & & \\
\hline Population (0-6) & $-.770^{* *}$ & .090 & 1 & & & & & & & & \\
\hline School/100 sq.km & .245 & .160 & .216 & 1 & & & & & & & \\
\hline Population/School & .239 & -.038 & .050 & -.074 & 1 & & & & & & \\
\hline Sex-ratio & $-.571^{* *}$ & -.321 & .297 & .044 & $-.506^{*}$ & 1 & & & & & \\
\hline Urbanization & $.704^{* *}$ & .253 & -.242 & $.463^{*}$ & $.613^{* *}$ & - & & & & \\
\hline Male literacy & $.828^{* *}$ & .314 & $-.550^{* *}$ & .261 & .206 & $-.523^{* *}$ & $.498^{*}$ & 1 & & & \\
\hline BPL ratio & $-.698^{* *}$ & $-.462^{*}$ & .270 & -.157 & $-.607^{* *}$ & $.692^{* *}$ & $-.838^{* *}$ & $-.642^{* *}$ & 1 & & \\
\hline Rural literacy & $.920^{* *}$ & .211 & $-.718^{* *}$ & .156 & .152 & $-.543^{*}$ & $.494^{*}$ & $.956^{* *}$ & $-.619^{* *}$ & 1 & \\
\hline Urban literacy & $.948^{* *}$ & .169 & $-.746^{* *}$ & .285 & .021 & $-.442^{*}$ & $.534^{*}$ & $.850^{* *}$ & $-.557^{*}$ & $.929^{* *}$ & 1 \\
\hline
\end{tabular}

**. Correlation is significant at the 0.01 level (2-tailed).

*. Correlation is significant at the 0.05 level (2-tailed).

Female literacy has significant positive correlation with level of urbanization, male literacy, rural literacy and urban literacy. Relatively favorable conditions such as availability of schools, teachers and supportive environment at home and safe outside environment are responsible for high literacy rate in urban areas. Likewise, higher male literacy in both rural and urban environment creates encouraging milieu for female literacy. Surprisingly, it has highly negative correlation with the sex ratio. It means higher sex ratio do not indicate improved social status of females. Kurukshetra Karnal belt has extremely low sex ratio but female literacy is fairly good. Rather, it proves the apprehension that there is large scale foeticide in the state. Since it has some cost to carry foeticide so poor and illiterates usually unable to misuse such technology rather, it is more rampant among the educated and economically well off families. Female literacy has very strong negative correlation with the proportion of BPL population and under 6 year's population. Both of these factors reflect the poverty, illiteracy and ignorance.

\section{Finding and Policy Recommendations}

Paper reveals that there is significant increase in female literacy rates; however, in rural area it is low as compared to urban but this gap is narrowing down. The high female literacy in eastern region is marked by a relatively high degree of urbanization, commercialization, dense network of roads, communication, availability and accessibility of educational facilities etc. Government need to have special attention on Nuh, Hathin, Punahana, Palwal and FerozapurJhirkatehsils of south-west Haryana. These tehsils are under developed and have a large proportion of Muslim population, so need to accelerate the development activities, awareness programme and financial assistance to weaker sections in those areas to increase the female literacy.

\section{References}

[1] Azim, S. (2005), Literacy growth disparities in Karnataka. Economic and Political Weekly, 40(16), 1647-1649.

[2] Chandna, R.C. (2009). Literacy in Punjab and Haryana2001. Punjab Geographer, 5, 116-120.

[3] Frey, R. S. \& Field, C. (2000). The determinants of infant mortality in the less developed countries: crossnational test of five theories. Social Indicators Research, 52, 215-234.

[4] Hassan, M. I. (2005). Population Geography. Rawat Publications, Jaipur.

[5] Jhariya, G. P. \& Jain, C. K. (2014). Pattern and differential of literacy in Madhya Pradesh. IOSR Journal of Humanities and Social Science, 19 (9), 77-84.

[6] Khan, A. Q. (2004). Regional imbalance and changing pattern of literacy in Jammu and Kashmir state (19612001). Population Geography, 26 (1, 2), 49-60.

[7] Kamat, A. R. (1976). Women's education and social change in India. Social Scientist, 5(1), 3-27.

[8] Krishan, G. \& Shyam, M. (1978). Regional aspects of urban-rural differential in literacy in India: 1971. The Journal of Developing Areas, 13(1), 11-21.

[9] Magadi, M. A., Agwanda, A. O. \& Obare, F. O. (2007). A comparative analysis of the use of maternal health 


\section{International Journal of Science and Research (IJSR) \\ ISSN (Online): 2319-7064}

Index Copernicus Value (2013): 6.14 | Impact Factor (2015): 6.391

services between teenagers and older mothers in SubSaharan Africa: evidence from demographic and health surveys (DMH). Social Science and Medicine, 64, 13111325.

[10] McGee, T. G. (1971). The Urbanization Process in the Third World (pp. 57). London: G. Bell.

[11] McTavish, S., Moore, S., Harper, S. \& Lynch, J. (2010). National female literacy, individual socio-economic status and maternal health care use in Sub-Saharan Africa. Social Science and Medicine, 71, 1958-1963.

[12] Ramotra, K. C. (2003). Spatio-temporal patterns of scheduled caste literacy in Kolhapur and Sangli Districts. In Patil \& R.B. et al., (Eds), Development in India: Anxieties and alternative paradigms (pp. 381394). Published by Prof S. N Pawar, Felicitation Committee, Kamala College, Kolhapur.

[13] Shafiqullah, S. (2011). Regional analysis of urban-rural differentials in literacy in Uttar Pradesh, India. Journal of Geography and Regional Planning, 4(5), 287-296.

[14] Shakir, M., Lone. A.H. \& Zafar, J. M. (2012). Measuring literacy mechanism and assessment of literacy levels in Pakistan. Social and Behavioral Sciences, 47, 391-395.

[15] Som, K. S. \& Mishra, R.P. (2014). Literacy and their differential in West Bengal. International Journal of Science and Research, 3(6), 1537-1545.

[16] Sule, B. M. \& Barakade, A. J. (2012). Literacy in Maharashtra (India). Geoscience Research, 3(1), 88-91.

[17]Census of India (2011). Retrieved from Escahttp://www.censusindia.gov.in/2011common/censu s 2011.html

[18] ESCAP (2010). Retrieved from www.unescap.org/jecf/p07women.htm

\section{Author Profile}

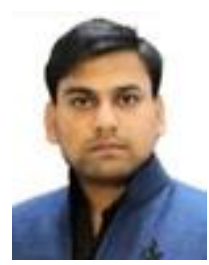

Ravinder Jangra has done his M.Sc., M.Phil. and now pursuing his Ph.D. on topic entitled "Assessment of Tourism Carrying Capacity in Selected Destinations of Cold Desert Area of Kinnaur District, Himachal Pradesh" from Department of Geography, Kurukshetra University Kurukshetra, Haryana.

S.P Kaushik is currently working as Professor, Department of Geography, Kurukshetra University Kurukshetra, Haryana -136119 has done M.A., M. Phil from JNU and Ph.D. Degrees from Delhi University. 